\title{
TESOROS DE LA CATEDRAL DE LIMA
}

$\mathbf{P} \mathbf{R}$

\section{EMILIO H A R T H-T ERRE}

$\mathrm{Z}^{\mathrm{N}}$ Los entalladores del siglo $X V I I$ destaqué como figuras principales, en Lima, a principios del siglo, a Juan Martinez de Arrona y a Pedro de Noguera. No pretende ser ese trabajo un panorama completo de la obra y artífices que en ese siglo se dedicaron a la escultura y tallado de imágenes y retablos, $y$ especialmente a estos últimos, pero sí es ya una aproximación a lo que más adelante y con copia de datos, habré de publicar en esta necesaria investigación de nuestro arte virreinal y como resultado de constantes y fructiferas investigaciones en nuestros nutridísimos archivos.

Tampoco alcanzaba el análisis completo del movimiento artístico y de la trayectoria evolutiva del renacimiento clásico hacia el barroco en las manifestaciones plásticas de estos artífices, aunque se esbozara en forma general una curva cuyos puntos determinantes se pretendía señalar con los nombres de algunos artesanos, al parecer, por ahora, más destacados en el arte de la ensambladura y del tallado. Aun falta -y probablemente falte para siempre por razón de su desaparición- descubrir toda la obra ejecutada por ellos para poderla analizar y comparar eficazmente. En el caso de Juan Martinez de Arrona y de Pedro de Noguera, que son dos puntos notables de esa trayectoria, sí es posible hacerlo porque 
tenemos a la vista, felizmente, buenas obras imaginadas y realizadas por ellos.

Este análisis, consiguientemente, contribuye a precisar ese panorama, destacando por el contraste entre uno $\mathrm{y}$ otro, un punto de la evolución del arte clásico del renacimiento al movimiento barroco, que quizá si llega algo tardiamente a nuestro territorio, luego brotará con muchísimo vigor, al punto de transformarse en sus posteriores florecimientos en un estilo con sentimiento y emoción propios, distinto del genuino arte español y capaz de poderle asignar un calificativo singular: el de barroco americano.

Nos será dable más tarde, a medida que vayamos precisando las fuerzas inquietas así como también los caracteres de este movimiento, determinar la verdadera calidad del barroco en América. En el Perú, especialmente, en donde una potencia racial y telúrica, alcanzó con su intensa vibración a torcer, no el carácter pero sí la forma del barroco, retornando a fuentes pristinas, puras y primitivas del arte español y luego hacia un renacimiento barroco, extremadamente caracterizado en ya señalada dirección desde medio siglo xvir.

Las obras que presentamos y vamos a comparar, están en el mismo monumento: la Catedral de Lima, cuya restauración se lleva a cabo descubriéndose su frontispicio de ricas piedras, unas oriundas de Panamá, para formar sus esbeltas columnas corintias, otras de Arica, más tenues y más porosas, o también de las canteras cercanas a la ciudad de Sisicaya o ,de Cañete, blancas espumosas. Más de una vez señalé la necesidad de devolver a nuestra Catedral su majestad y calidad formal, limpiándola de los revestimientos con que se había querido disimular la herida de sus sillares, causadas por el tiempo y por los temblores y terremotos. ${ }^{1}$

Esa era la obra de Juan Martínez de Arrona, en los últimos años de su vida y que había proseguido su discipulo Pedro de Noguera, sin darle término ninguno de los dos, por las circunstancias del tiempo. La obra arquitectónica de quienes habian embellecido su interior, con magníficos tallados; "escultores" que luego con igual desenfado y capacidad, actuaban como "Maestros Mayores del arte de la Arquitectura".

Uno de estos trabajos es la Cajonería de la Sacristía, que ejecutó Juan Martínez de Arrona; otra, es la Sillería del Coro que llevó a cabo Pedro de Noguera. Tanto la Cajonería como la Sillería son a mi juicio,

1 La restanración completa de la Catedral de Lima oe lleva a cabo, en la actualidad, de acuerdo con los plano: del Arquitecto Emilio Harth-terré, antor de eate estudio, y bajo su supervigilancia como Miembro del Consejo Nacional de Restauración y Conservación de Monumentos del Perá. 
aparte de unas de las más antiguas y mejor conservadas obras de tallado que hay en el Perú, también ejemplares valiosos del arte virreinal. No hay en esto un acrecentamiento de méritos. El trabajo vale y su admiración nos comunica su calidad y valor.

Por curiosa e involuntaria injusticia de la Historia, el nombre de Juan Martínez de Arrona había permanecido oculto mientras el de Pedro de Noguera brillaba con esplendor y su recuerdo era más vivo. El había continuado las portadas de la fachada; su nombre se había citado por algunos viejos cronistas y él mismo habia probablemente contribuido a hacer más perenne su recuerdo, por su genio y su carácter y su afanoso hacer de cosas y afianzamiento de títulos y prebendas, pero sin que a mi juicio, reste mérito alguno al trabajo de Pedro de Noguera. Sin duda alguna que su genio inquieto contribuyó a esta perennidad: la vibración de su personalidad -y esto es un mérito- apagó a la de Juan Martínez de Arrona, apacible y tranquila, más grande en su modestia y en sus afanes. En un análisis más genérico, el barroquismo de Noguera que se avenia a su genialidad, cubrió con su brillo el fuego del clasicismo renacentista de Martínez de Arrona. En estos dos hombres y en el recuerdo de sus nombres en la Historia, hay una imagen del arte virreinal del siglo $x v i x$. El barroco hispánico apaga el arte de cepa clásica, más ligada a lo romano que a los acentos castellanos. (No olvidemos que Martínez de Arrona, aunque discípulo o admirador de Becerra y continuador de su escuela, mantenia su espíritu ligado a muchas tradiciones técnicas hispánicas.)

Esto mismo nos lleva a decir y asegurar que el mayor reconocimiento de nuestros artífices, es decir de su vida y de sus obras, nos permitirá juzgarlas mejor y compararlas en el gran conjunto, con más realismo y viveza. Después de todo, la obra de arte es una obra de vida: la descripción escueta de cualquier trabajo de arquitectura no es sino un análisis anatómico de autopsia artística que puede interesar en su fondo pero no lo será tanto en la calidad. I a obra de arte por ser obra de vida, debe estar animada en nuestra inteligencia con la vida misma que creó esta obra; y la vida de sus artistas y el panorama histórico que le sirve de fondo no ha de ser la bambalina teatral para que el personaje declame la comedia sino el cuadro en que se fundan unas y otras y nos dé la visión estereoscópica y cinemática de todo ello; y también nos ponga en contacto más íntimo para que podamos saborearla inmejorablemente.

En el año de 1608 resolvió el Cabildo llevar adelante la necesaria obra de la Cajonería de su Sacristía. Y para los efectos de esta obra comisionó a don Fernando Arias de Ugarte, oidor de la Real Audiencia, y a don Fe- 
liciano de la Vega, canónigo de la Catedral, para que examinasen y aprobasen la memoria presentada por Juan Martínez de Arrona, "Maestro de escultura", para dicha obra. La traza y modelo presentado por el Maestro, según sus propios términos, "componiase de dos géneros, corintio y compósito que son los más aventajados en hermosura, riqueza y majestad, de los cinco que la arquitectura en sí contiene; con la figura del Salvador en medio y en los lados sus doce apóstoles de medio relieve".

En la misma memoria hacía referencia a la ejecución de un retablo que se colocaría en la testera de esta pieza. Retablo de dos cuerpos, que desapareció cuando más adelante, a principios del siglo xvir, se construyó la Sala Capitular en el sitio en donde existía hasta entonces una pieza destinada a guardar el monumento de semana santa, y fuera por lo mismo necesario abrir un vano para la comunicación de la Sacristía con esta nueva oficina de la Catedral. La ejecución de este retablo y su forma eran sugerencias del Maestro. "Ya había conferido con don Feliciano de la Vega, esta obra", dice en su memoria y añade de que para ella tenía comprados 2,500 pesos de madera de cedro.

Por la obra de la Cajonería, Juan Martinez de Arrona cobraba $\mathbf{5 . 5 0 0}$ pesos de a nueve reales y, aprobada que fué y decidido el trabajo, el Cabildo concertó su ejecución el 19 de mayo de 1608 ante el escribano público don Cristóbal de Villanueva.

¿Qué acreditaba a Martínez de Arrona como escultor para que se le confiara la obra? Sin lugar a duda, en primer término, la traza, que debió ser bien atrayente. Conocemos la mano de dibujante de Martínez de Arrona, en el croquis que hiciera para la puerta principal de la Catedral de Lima y que se adjuntó al concierto celebrado para tal efecto, conservado en la actualidad en los Protocolos de don Bartolomé de Civico, Escribano Público. ${ }^{2}$ También habían de influir sus obras ya ejecutadas; se conocen algunas por documentos contemporáneos. En 1599 se concertó con los Mayordomos de la Cofradía de los Herreros y Caldereros de San Laurencio para esculpir en madera de cedro la imagen del venerado patrón, que debía ostentar en sus manos las parrillas de su suplicio y la palma de sus virtudes. La imagen tenía siete palmos de altura, estofada, encarnada y con su respectiva peana. ${ }^{3}$

2 Bartolomé de Civico. Escribano Público. Fol. 2637 de su registro del año 1626. Archivo Nacional del Perú. Dibujo en pergamino en tinta y lápiz. Reproducido con un comentaxio, por el autor de eate estudio en Ia revista El Arquitecto Peruano. Julio. 1941. Lima.

3 Artonio Corvalan. Escribano Pablico. Fol. 250. 1597-60. Archivo Nacional del Perú. 
En 1604 volvió a ejecutar otro, pero esta vez "hueco por dentro, que pese poco", también estofado y encarnado. "En 1605, el Maestro recibe el encargo del Regidor don Francisco de León, Mayordomo de la Cofradía de Nuestra Señora de la Visitación, para que tallara dos imágenes, que iuego dorarían y estofarian, representando la Visitación de la Virgen María a Santa Isabel y que iban a reemplazar otras semejantes, pero más antiguas que existían en el mismo retablo. Por ciertos documentos es presumible la presencia de Martínez de Arrona, en el Cuzco, en los primeros años del siglo, ( $t$ con Becerra, para la Catedral ?) y todo esto pasaba ante el buen criterio de los canónigos, para encomendarle la obra. A lo que venia a añadirse su gran deseo de trabajar y su humilde afán de llevar adelante la gran obra de la Catedral de Lima.

El dibujo de Juan Martínez de Arrona recibió algunas enmiendas por parte del Cabildo Arzobispal. Las figuras de los apóstoles se aumentaron a catorce: Matías que reemplaza a Judas Iscariote (que innegable servicio prestó al proceso de la Redención) y San Pablo y San Bernabé que también son considerados como apóstoles y como tales los honra nuestra Iglesia. Y en medio, la magnífica imagen del Salvador, abiertos los antebrazos en éxtasis, con un ropaje de pesada opulencia, que caracteriza las figuras escultóricas de las decoraciones españolas del primer Renacimiento y de directa influencia italiana. Sin embargo, las figuras de Martínez de Arrona no tienen todavía, o mejor dicho se resisten al liberal movimiento que esa escuela daba a sus figuras. Hay en ellas aún cierto estatismo gótico, esencialmente del primitivo italiano del cuatrocientos, quizá porque Martinez de Arrona haya recibido lecciones de algún maestro castellano, o él mismo fuera oriundo de tierras más mediterráneas de la península Ibérica.

Resiste el dibujo de ellas al más severo análisis. En cuanto al tallado, su técnica no desmerece a la de los buenos maestros españoles. Las formas escultóricas del primer renacimiento italiano que se trasladaron a España por los mismos maestros toscanos, llegaban tardiamente al Virreinato del Perú, a la Ciudad de los Reyes. No se dejaba aún sentir en la obra del Maestro Martínez de Arrona, la influencia que Miguel Angel imprimió a la escultura española desde el primer tercio del quinientos y de la que Berruguete fuera inmortal intérprete de sus tendencias en la Metrópoli. Pero tal se vió en España pasar la escultura de las formas del primer re-

4 Franciaco Ramiro Bote, Escribano Público. Fol. 1508 vta. 1604-05.

5 Alonso Carrión, Escribano Público. Fol. 871 vta, 1602-06. Archivo Naeional del Perá. 
nacimiento a la influencia del gran Buonarotti, sin transición, así igualmente veremos cómo, de Martínez de Arrona en su Cajonería de 1608, a Pedro de Noguera en su Sillería de 1623, se pasa igualmente del medio relieve, en figuras de un marcado academismo lineal, a las formas más enérgicas y hasta violentas, cuyos miembros empiezan a sobresalir de la tabla. A una comparación más prolija y completa llegaremos más adelante. Antes, destaquemos brevemente el carácter florentino de los menudos adornos y tallados de los tableros de cajones y roperos, "grutescos" cuya delicadeza, fragilidad y elegancia son pasmosamente toscanos y es digno de tomarse en consideración para estudio más profundo de las influencias itálicas, en su alcance hasta estas playas, traídas por las corrientes españolas sin filtro ni menoscabo.

Era por entonces, Martínez de Arrona, de edad de cuarenta y seis años. En su carta de examen, de 28 de septiembre de 1612, declaraba tener cincuenta. De temperamento sencillo, modesto y apacible, era de buen lenguaje y magnífica caligrafía. Su dibujo era pulcro y prolijo; los. términos que empleaba en sus memorias lo hacen entrever como hombre delicado no exento de firmeza y voluntad. Su afán por terminar la obra de la Catedral de Lima revelan su carácter. Desde 1614 o quizá en el 13, es su Maestro Mayor, $y$ en ese año emite su parecer sobre la forma de las bóvedas, para proseguir las obras del templo, solamente ejecutado hasta. entonces en su mitad posterior. "Los cerramientos que están por hacer, se hagan de cruceria y no de arista", manifiesta, y con esto descubre que si bien admiraba $y$ ponja en práctica las influencias arquitectónicas de Becerra, que traía a nuestras tierras el arte oficial de Herrera, y en el dibujo y tallado prosegúa en las maneras y técnicas del primer renacimiento, en su técnica arquitectónica estaba aferrado, por estudio o natural inclinación, a los tradicionales métodos de la arquitectura castellana prerrenacentista que aún en principios del siglo xvrr, en América, prevalecían en extraordinaria supervivencia.

En 1626 se empeña en que la obra de las portadas llegue a término. La iglesia ha quedado expedita hasta el atrio de la Plaza Mayor, pero los trabajos se prosiguen con calma, con demasiada calma para los afanes de Martínez de Arrona que siente el peso de los años y cuenta sus últimos. días. Todo es cuestión de dinero. En el interior se llevan a cabo las obras de adorno. El coro y retablos en las capillas de las naves laterales. Para las portadas las posturas arrojan sesenta mil patacones, precio subido a juicio de la Audiencia y del Cabildo. Mezquindades injustificadas cuando los galeones llevaban el oro a raudales a la Metrópoli y se reclamaba 
la autoridad urbana de la Ciudad de los Reyes. Hacía falta un Virrey, como don Juan de Mendoza y Luna, Marqués de Montesclaros, emprendedor y resuelto, o uno como Francisco de Borja y Aragón, Príncipe de Esquilache, y no por poeta menos decidido y determinado. Don Diego Fernández de Córdova que a la sazón reinaba en el Perú, estaba atribulado por la presencia de los piratas en los mares del Pacífico, la fortificación del Callao y el amurallamiento de Lima, que no le dejaban suficiente sosiego para rematar con belleza lo que ya se había edificado con fortaleza. ${ }^{8}$

Aqui Martínez de Arrona descubre que la obra puede seguirse por mitad del precio de las pujas. El puede llevar adelante la obra por treinta $y$ seis mil patacones y una mejora de seis mil más por el trabajo que había de tener en la terminación de los tres ültimos arcos. Que le den dos negros viejos esclavos, que trabajan en ella, y todos los aderezos que hay en la construcción: pies derechos, tablas, varas de mangle para los andamios y las herramientas "que aunque son muy viejas y tienen poco valor pueden servir". " $Y$ con estas condiciones - afiade- aunque sea aventurado a perder como le ha sucedido siempre por cuya causa está pobre, con todo esto lo tendré por bien empleado por el gran deseo que tiene de dejar acabado de todo punto y de su mano antes que muera"... $\mathrm{Y}$ así, con sus colaboradores Acosta, Lobo, Cabezas, etc, se pone a la obra.

Pero retornando a la Cajonería, al pie de la imagen del Salvador, que talla en espesa tabla de cedro, Martínez de Arrona puso, inspirado por sus sentimientos o por orden ajena, la palabra del Evangelista Mateo: "Venite ad me omnes qui laboratis"... "Venid a mi todos los que trabajais"... fruto del fervor con que se animaba en su vida y en su artística y paciente, pertinaz y perseverante obra. Fué, como siempre, su lema en la prolongada obra de escultura, arquitectura o tallado que realizó en esta ciudad.

En el año de 1619 está yà Pedro de Noguera en Lima. Se pretende que el tal Maestro es oriundo de Sevilla, en donde su padre -y élfiguran como arquitectos de retablos en los años de 1612 y 1613. Las

6 Para ver la importancia personal de Jaan Martínez de Arrona, por entonces, basta señalar que en 12 Janta que tuvo lugar en el año 1624 para discutir el cerco de la ciudad de acuerdo con una provisión Real y con la presencia del Virrey Marqués de Guadalcázar. el único alarife presente fué Juan Martínez de Atrona $¥$ el Capitán Rodrigo Montero de Duarte. Ingeniero, quienes dieron sus pareceres sobre ésta y otras obras más consultadas por el Virrey. (Legajo de Documentos Importantes. Archivo Arzobiepal de Lima.) 
afirmaciones de Muro y de Bago son plausibles. Se reclama, sin duda alguna, una confrontación mejor; por ejemplo, la igualdad de la firma en los documentos oficiales ... De todas maneras, y mientras ponemos la mano sobre su testamento o algún otro documento que tal declara, Pedro de Noguera demuestra ser un hábil artífice y un excelente escultor. En el año mencionado, Pedro de Noguera se obliga con los Mayordomos de la Cofradía de la Soledad, fundada en el Convento de San Francisco de Asís de esta ciudad, para esculpir, estofar y encarnar la figura de un Cristo crucificado, que había de tener articulados los brazos a la altura de los hombros, y las piernas, en las rodillas, para poder hacer, en cada oportunidad, el descendimiento de la Cruz. ${ }^{7}$ Noguera cumple hábilmente su cometido en 1620 . En el año siguiente se sabe que contrae matrimonio con doña Ursula de Bonifacio, limeña. En este acto declara ser natural de Barcelona y ser hijo legítimo de don Pedro de Noguera y de doña Juana. ${ }^{8}$

En el año de 1622 demuestra sus conocimientos y habilidad al concertar la ejecución del retablo para la Capilla Mayor de la iglesia de Nuestra Señora de los Soldados, fundada en el Convento de San Francisco del Callao. El tamaño y altura del retablo serian "lo competente para cubrir desde el altar hasta la armazón del techo". El sagrario debía de labrarse conforme a la traza, "guarnecido alrededor de agallones y dentro de él, debian de ir las figuras de pintura que quisiere el P. Guardián". Los recuadros llevaban "figuras historiadas conforme a las figuras pinta. das abajo". Las columnas del sagrario eran estriadas y luego doradas y matizadas y el arco principal del mismo se decoraba con figuras. El banco principal se adornaba con seis vanos, tres a cada lado que serían recubiertos de pinturas. La comisa colocada sobre cuatro columnas estriadas, redondas, doradas y matizadas, debía ir con sus canes, friso y arquitrabe. El friso seria "estofado de grutescos y molduras y el remate superior con su frontispicio, y arbotantes". Continúa este larguísimo concierto dándonos más detalles de esta obra: una imagen de la Concepción se colocaria en la caja principal y sobre ella una corona a la que se pintarian resplandores de nubes y serafines y alrededor del cuerpo, otros rayos resplandecientes conformes con los de la corona. $Y$ a los lados de la caja, irían es-

7 Francisco Hernández, Escribano Público. Fol. 1434, 1619. Archivo Nacional del Perú. $163 \mathrm{vta}$.

8 Parroquia del Sagrario. Libro IIl de Matrimonios Españoles. 1609-39. Fol. 
tofados de grutescos y de espejos. Para el remate del retablo, esculpiría la figura de un Cristo, cuya cruz debía medir una vara y media.

Como un detalle de la prodigalidad con que se celebran estos contratos, se exigía además al Maestro entregar dos llaves, "labradas con toda curiosidad", para la cerradura del sagrario.

He reproducido todos estos detalles porque en los términos del concierto está la explicación de las tendencias escultóricas de Pedro de Noguera. Retablo este último que ha desaparecido por el cataclismo que asoló al puerto de Callao en 1687, pero queda de él el concierto minucioso y detallado. Alli están los agallones a los lados del sagrario; las columnas estriadas y redondas -como podemos verlas en la sillería del coro- los grutescos y los espejos, detalles todos del renacimiento clásico. Más tarde repetirá estos mismos elementos arquitectónicos para soportar las tablas talladas con la imagen de los apóstoles y los santos en los escaños de la Catedral. Efectivamente, a poco de realizado este retablo por Pedro de Noguera, en 1623, se hicieron posturas para llevar adelante la obra de la custodia y sagrario del altar mayor de la Catedral de Lima. Obtuvo la buena pró por cinco mil pesos. Al mismo tièmpo se presenta para efectuar el trabajo de la silleria. Por entonces ya había en Lima buenos entalladores. Se recuerda como figuras principales a Luis Ortiz de Bargas, a Louis de Espinola y Villavisencio, Martín Alonso de Messa, Gaspar de la Cueva y otros de menor cuantía pero no menos activos y capaces: Gabriel Ordónez, Rodrigo de Padilla, de la vieja escuela plateresca, Antonio de Umbela, Juan de Cáceres y otros más y muchos oficiales, discípulos de unos y otros y que más adelante continuarian la vieja tradición de sus maestros.

Pero estos áltimos no eran de talla para competir en obra de tanta magnitud como la que se sacaba a remate. $Y$ a él solamente preséntase Ortiz. de Bargas que ofrece ejecutarla por sesenta mil pesos, $y$ además la verja, tribunas del coro y el púlpito. Noguera hace una rebaja a cincuenta y siete mil pesos. Luego se ofrece Martín Alonso de Messa por cincuenta y tres, Luis de Espinola pretende sacarla por cincuenta mil, pero Pedro de Noguera deseoso de la obra, rebaja a cuarenta y siete mil. Todo parece que queda alli terminado, pero a poco Gaspar de la Cueva hace sobre los planos de Noguera una propuesta aún más baja: treinta y nueve mil pesos. No es rivalidad ni competencia: es un desuñar incomprensible entre viejos maestros. Pero Noguera tiene afán de la cosa y la remata

9 Marcos de Santisteban, Exribano Páblico. Fol, 151. 1622. Archivo Nacional del Perí. Tomo I. 1935. 
definitivamente por treinta y ocho mil. ${ }^{10}$ Más tarde se quejará al padre Bernabé Cobo, el historiador de Lima, que este precio no le paga su trabajo. Como si él no se las hubiera buscado rebajando en las posturas. $Y$ he aqui al Maestro con las manos sobre la obra. La tarea es ardua pero se dará maña no sólo para prolongarla sino también para sacar más provecho de ella, ahora que se da cuenta del aprieto en que se ha metido. Ha llamado a su lado al Maestro y competidor Ortiz de Bargas para que le ayude. A éste le corresponderá ejecutar el lado derecho y la reja grande de la puerta del Coro, y él se encargará del resto y del púlpito. Noguera embromó las cosas, mejoró su precio y redujo el trabajo, al punto que no llegó a hacer el púlpito, pues éste recién se ejecutó en 1664, muerto ya el Maestro Noguera, por Diego Agnes, en 3,200 pesos que pagaron por manos de don Francisco de Elduayen, Mayordomo de la Fábrica de la Catedral de Lima. 11

Pero, analicemos la obra de Pedro Noguera y comparémosia con la de Martinez de Arrona.

La presencia en Lima desde 1619, sus posibilidades de ser oriundo en su arte de Sevilla, y los términos del concierto que hemos descrito en líneas anteriores para la ejecución del retablo de Nuestra Señora de los Soldados en la iglesia de San Francisco del Callao, nos permiten suponer que Noguera está poseído del espiritu del primer renacimiento en lo que respecta a la arquitectura la que emplearía como fondo de sus entalladuras y esculturas, pero en cuanto a éstas, ya no sentía el apego a los medios relieves y a esa composición y movimiento académico y lineal de sus imágenes. En Noguera bullia el espiritu barroco en la escultura, como figura aparejada de su arte a su personalidad la que también era bullente $e$ inquieta. A fines del primer cuarto de este siglo, se destacaba entre los escultores jóvenes un deseo de romper con los viejos cánories de la escuela tradicional hispana y olvidar las imposiciones más modernas del arte oficial de Herrera. Llegaban de Espafia, además, muchos dibujos para retablos y otras obras de escultura de gran envergadura, para que no se sintiera la influencia de la metrópoli en la iniciación del movimiento barroco. Aunque todo era más lento y tardio, porque igualmente se hacia sentir la influencia de los maestros clásicos del bajo renacimiento y de las escuelas italianas con la presencia de las traducciones y ediciones en castellano de León Batista Alberti por Lozano (1582), Vitrubio, por Urrea

10 Archivo de Indias. Sec. V. Audiencia de Lima, 587. (71-3-18). Publicado por el Padre Rubén Vargas Ugatte, en Manuscritos Peruanos en el Extranjeco.

11 Bernabé Cobo. Historia de la Fundación de Lima. Libro II. Cap. v. 
(1582) Vignola, por Caxesi (1593) y hasta dibujos del mismo Serlio, cuya publicación aun más antigua, por Villalpando (1565), circularon en Lima en manos de los maestros del arte e influyeron más tarde para la ejecución de algunos artesonados y portales.

Nada extraño que Noguera se sumara magistralmente a este movimiento, que en la Escultura ya había sido ampliamente difundido en todo el último medio siglo xv, por los trabajos de Alonso Gonzales de Berruguete y sus discípulos. Como que podemos comparar la obra de Noguera dentro de esa escuela de la que todavia se apartaba Martínez de Arrona, a pesar de haber ya traspasado las fronteras del Océano y alcanzado a América en algunos ejemplares, erigidos en iglesias de Lima. ${ }^{12}$

Pedro de Noguera ha comenzado por destacar valientemente sus figuras del fondo que las soportan. Las cabezas y las extremidades son exentas y la luz y la sombra las rodea y juegan en el espacio libre dándoles más vigor y movimiento. La obra de Noguera así, no queda ya en el dibujo, pasa verdaderamente a la escultura y los entalladores que to seguirán se sienten alentados para conquistar para sus figuras, el espacio con todos sus contrastes.

Por otra parte Noguera se resuelve en ciertos desnudos, $y$ como obligatoriamente sus personajes han de llevar indumentaria y vestimentas amplias, los desnuda en los brazos o en el pecho, lo más posible, para poder mostrar la anatomía del personaje y esmerarse en la talla de músculos y tendones y nutridas venas, que parecen tensos en un esfuerzo o comprimidos por un exceso de vitalidad.

Mientras Martinez de Arrona continuaba estilizando sus personajes; reduciendo la proporción de la cabeza a un octavo, Pedro de Noguera vuelve a la naturaleza proporcionándolas solamente a un séptimo, como ordenan los cánones barrocos.

Sus personajes cobran un aire más tierno e infantil a pesar de su augusta figura, mientras que Martínez de Arrona se mantiene en la clásica severidad por haberles dado ese ritmo equilibrado y austero. La in-

12 En 12 iglesia de Nuestra Señora de la Concepción de Lima exiute un retablo que fue traido de Sevilla 2 raíz de la construcción del templo. es decit, por los años de 1602 a 1604. por el que se babía pagado 1.300 ducados, costeados por dota Petronila de la Veqa. Mís tarde este retablo fú restaurado por Fr. Cristóbal Caballero. ecultor, en 1683 y en el siglo XVill suftí nuevas tranuformaciones conservando miempre las tabla talladaz en alto-relieve de fines del siglo XVI. y de manos de artiatas de la metrópoli. lo que to hace a la par que interesante en on estudio, valiowo en au conservación. 
quietud de las esculturas de Pedro de Noguera contrastan asi con la firmeza de las de Martínez de Arrona.

La escultura de Arrona concuerda con el espíritu de los apóstoles y la magna actitud de éxtasis de su Salvador. Los tallados de Noguera están de acuerdo con la personalidad de los santos de los doseles. Apóstoles y mártires: oración y lucha...

Pedro de Noguera da un nuevo sentido a la línea, que no es ya contorno de figuras sino relieve de colúmenes $y$ que hacen el magnifico juego de la luz y de las sombras.

Sin embargo, Pedro de Noguera no escapa en el adorno de su arquitectura y en sus grutescos, a un acento y trasunto plateresco. EI adorno de los fustes y especialmente las columnas del asiento arquiepiscopal son una buena muestra de ello. Conserva para la organización de los órdenes clásicos, la esencia y forma que Martírez de Arrona explaya en su fachada catedralista y que Noguera trató de romper en las portadas laterales. Muchos elementos ejecutados por el primero se repiten en la obra del segundo, así, por ejemplo, son dignos de notarse los pinfones y jarroncillos, de asas amplias, que Martínez de Arrona dibujara - sin. llegar a realizarlos para coronar el primer cuerpo de la portada mayor de la Catedral de Lima, en 1626 y que hallamos en el mentado croquis que . hizo ese año para proseguir la obra de ellos.

Pedro de Noguera será Maestro de Sillerías. De la Catedral saldrán las de San Francisco de Lima y las de la Catedral y San Francisco del Cuzco, tendencia, cuya similitud entre ellas es muy grande, con acusado mimético, y todas ellas ejecutadas posteriormente en todo el medio siglo $\mathrm{xvIr}$.

Como dijimos anteriormente, parte de esta silleria fué realizada por Luis Ortiz de Bargas, con quien Noguera se concertara en el año siguiente. Luis Ortiz de Bargas, hacía poco que estaba en Lima, probablemente llegaba en la época que se hacian las posturas para esta obra del coro; traía consigo varios dibujos de retablos y uno de ellos fué aprovechado para ejecutar uno en la Recoleta dominica de esta ciudad, en concierto con fray Jerónimo Bautista, de esa orden. Está dicho que a éste correspondióle hacer "el lado derecho" pero hoy seria difícil precisar qué parte hizo uno y otro, pues a principios de este siglo, se traslad́ la sillería del coro, de su primitivo lugar, al presbiterio, a los costados del altar mayor; alterándose su original disposición. Un más paciente y detallado análisis de las figuras podria darnos la diferencia de mano, pero no establecer la diferencia de las de Noguera con las de Ortiz de Bargas. No es presu- 


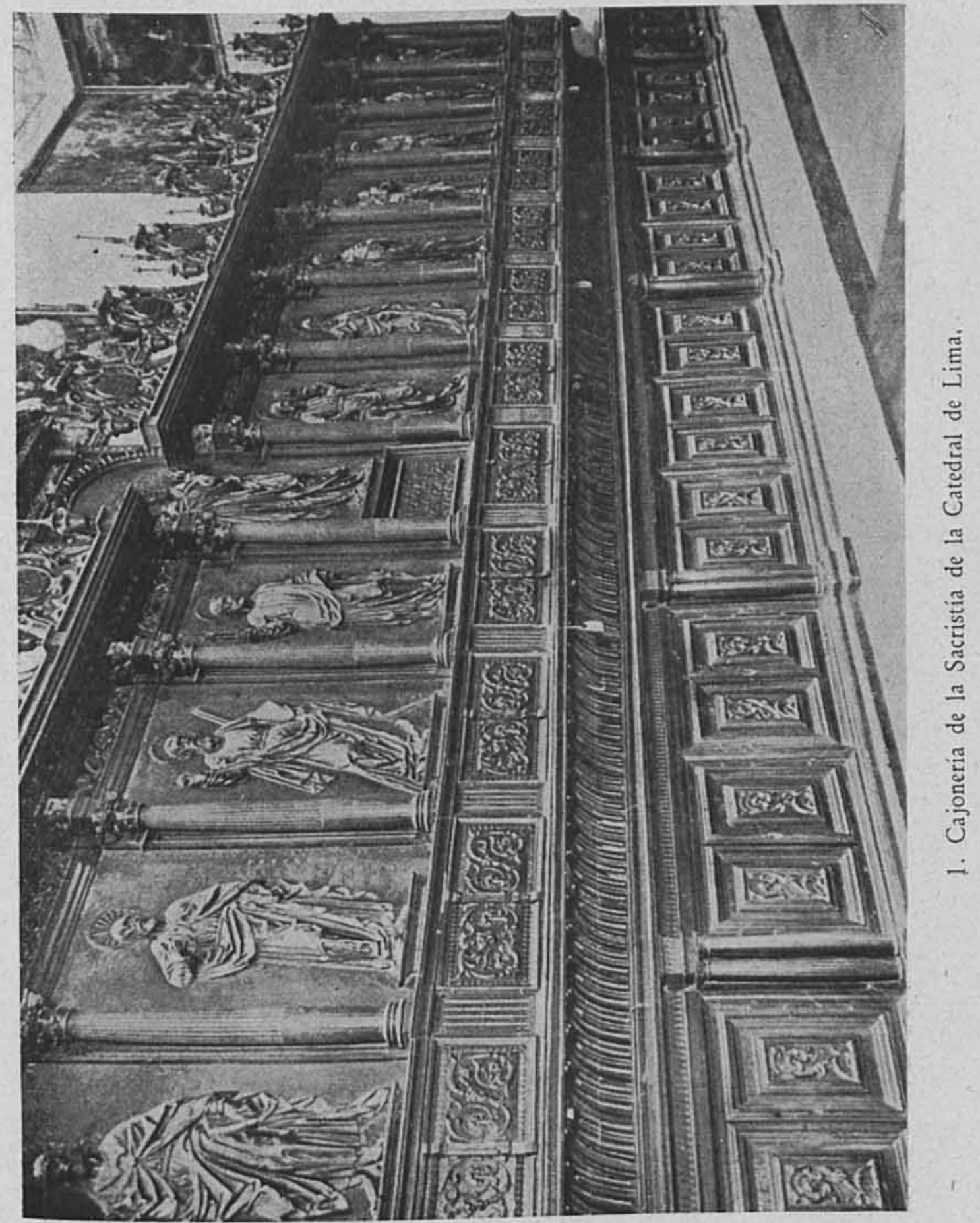



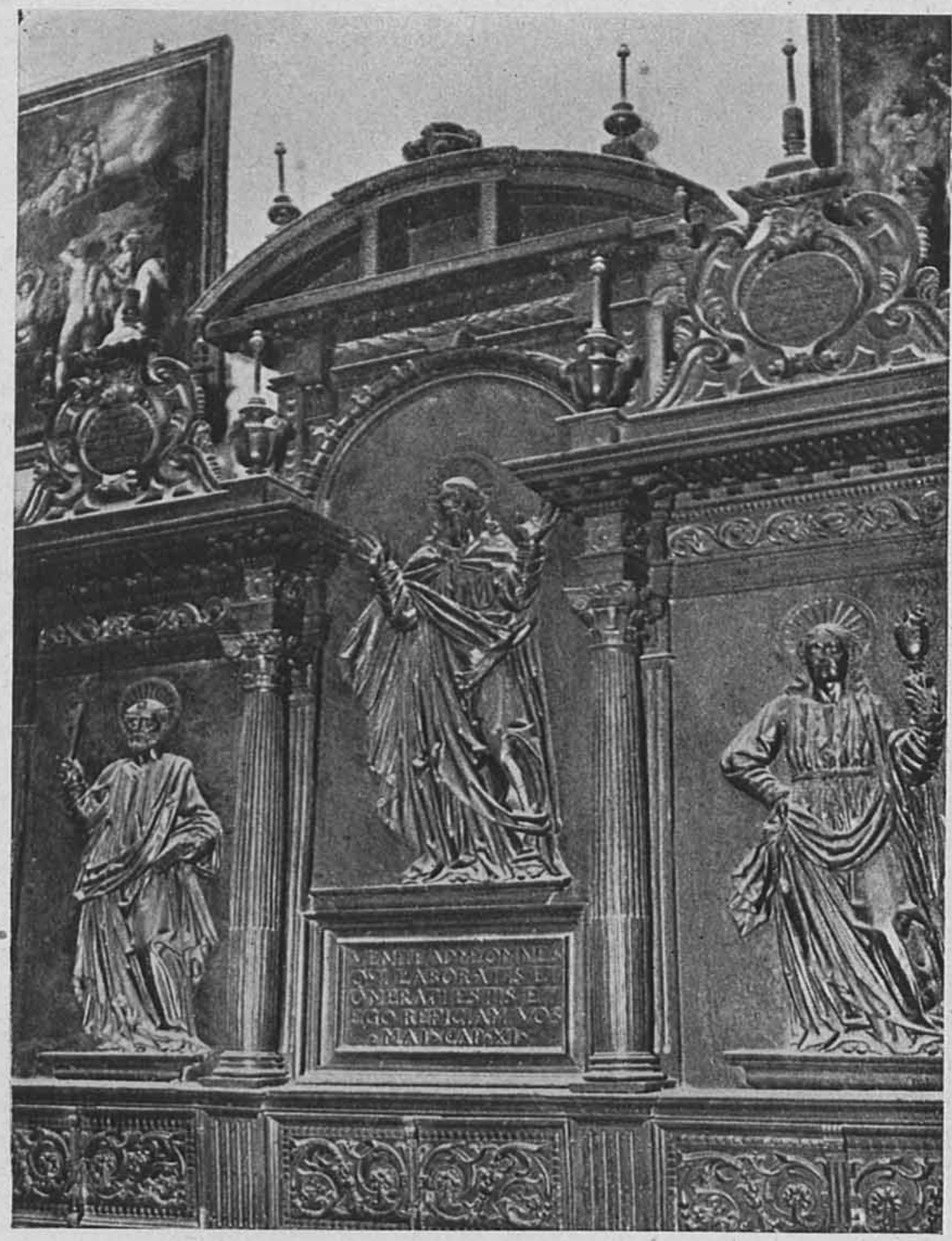

2. Figura central de la Cajonería. 


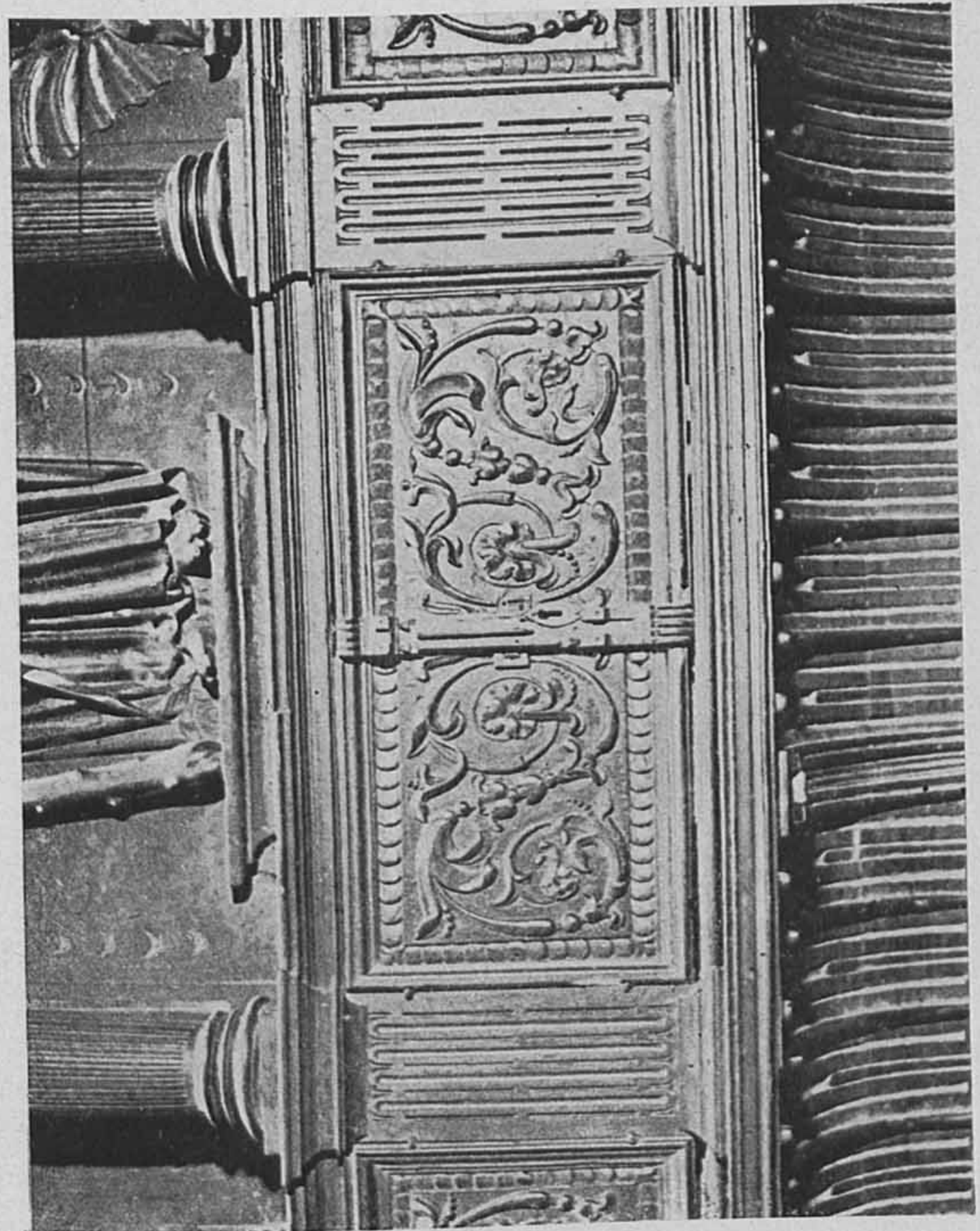

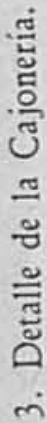




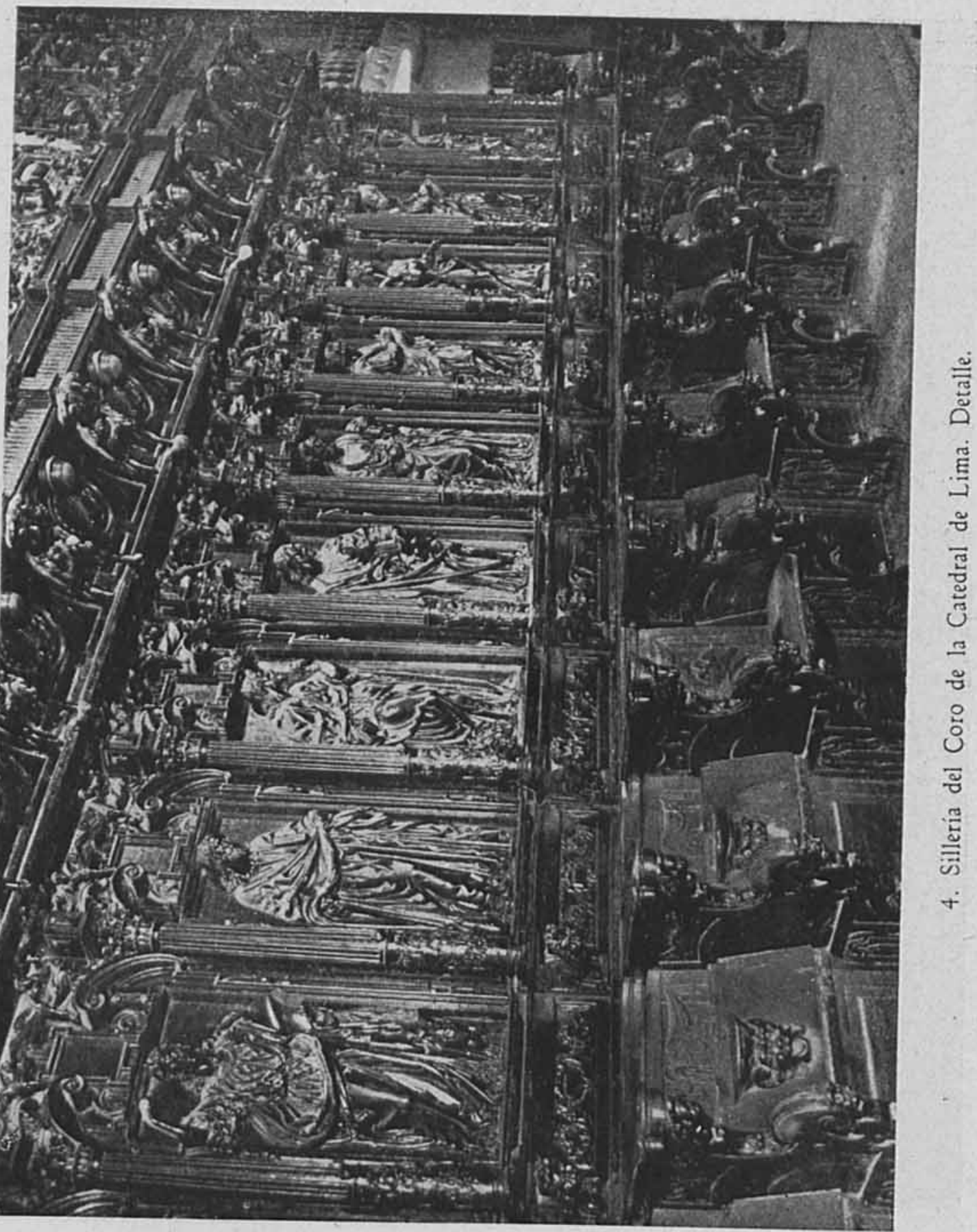




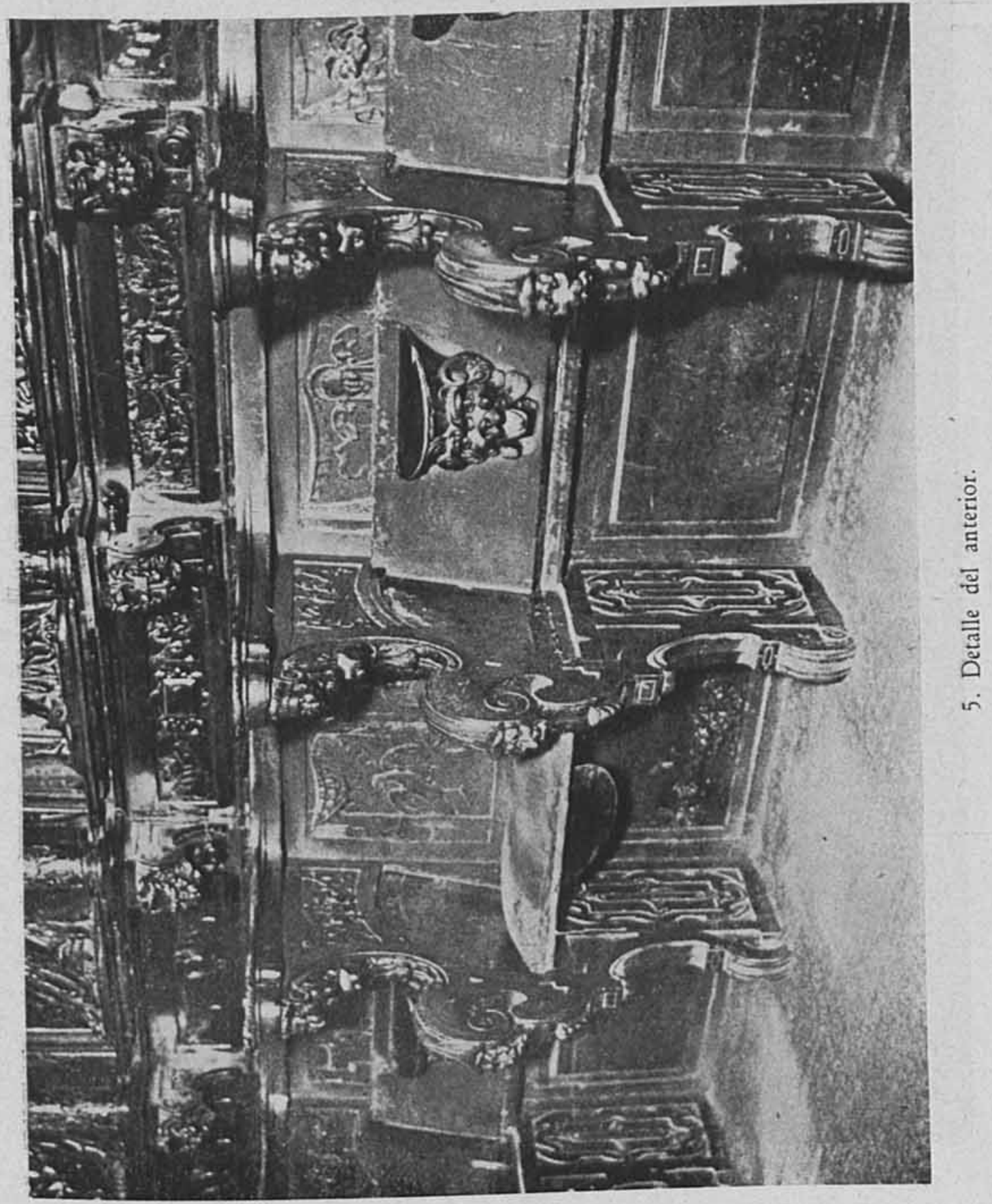




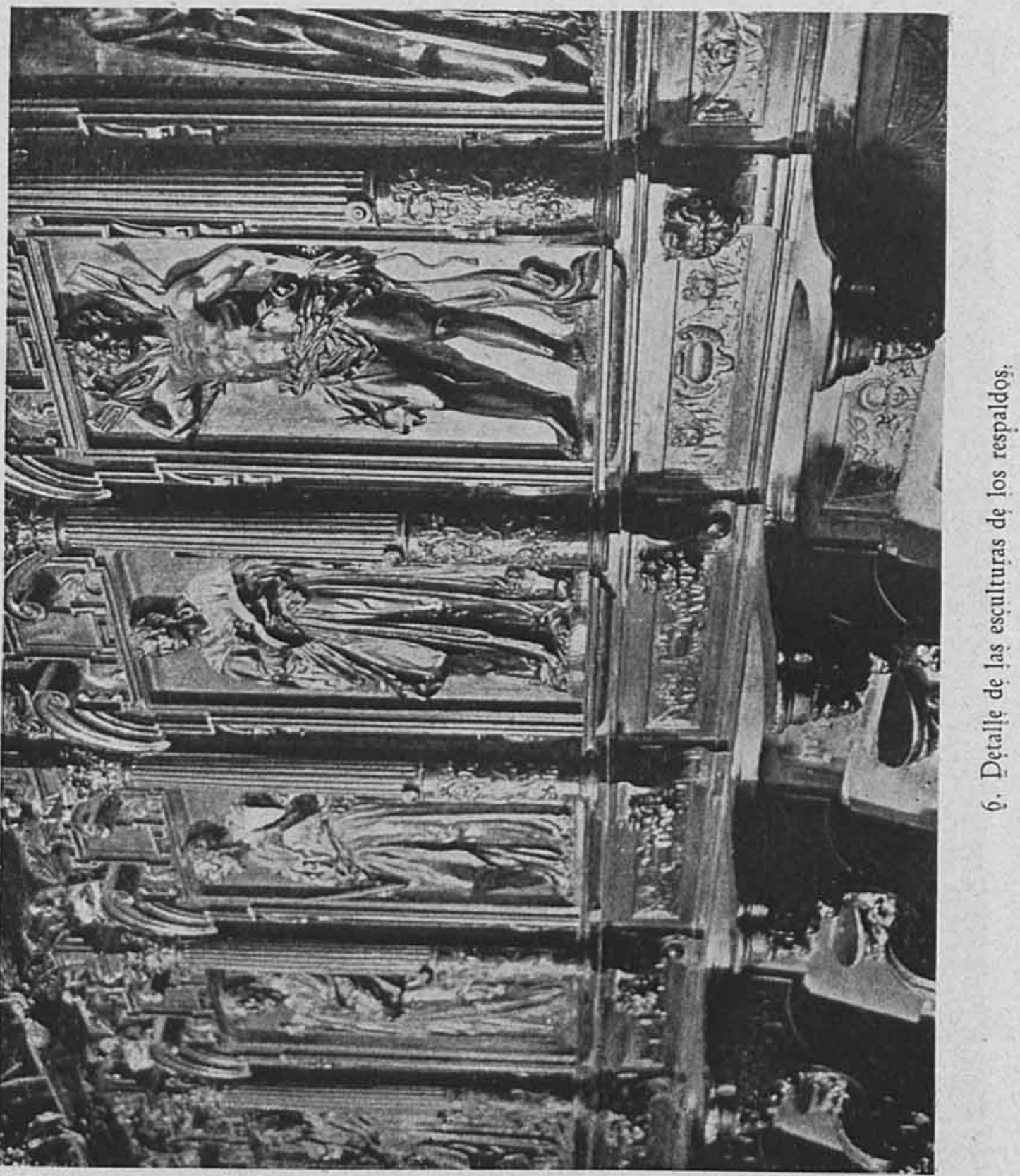




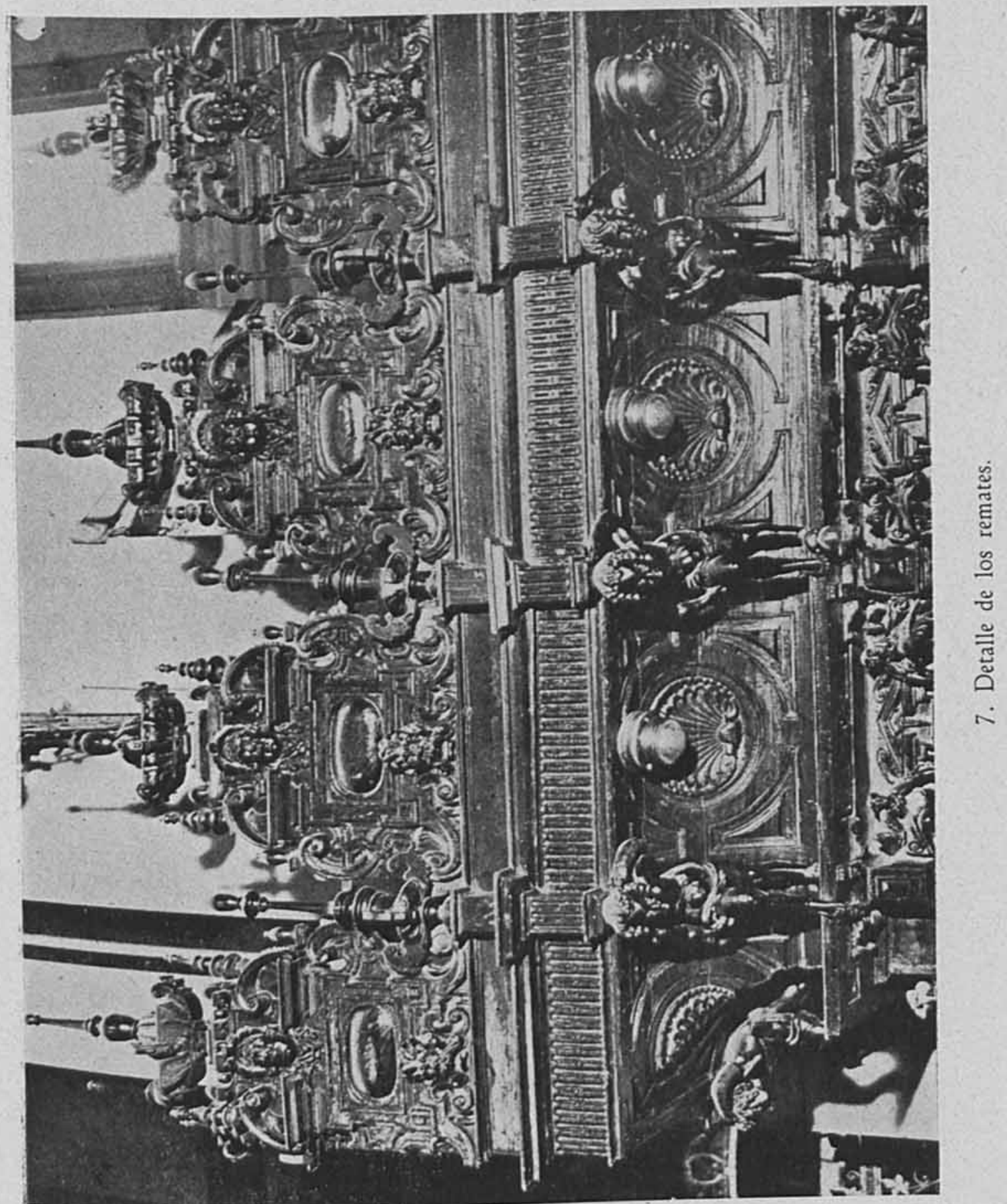




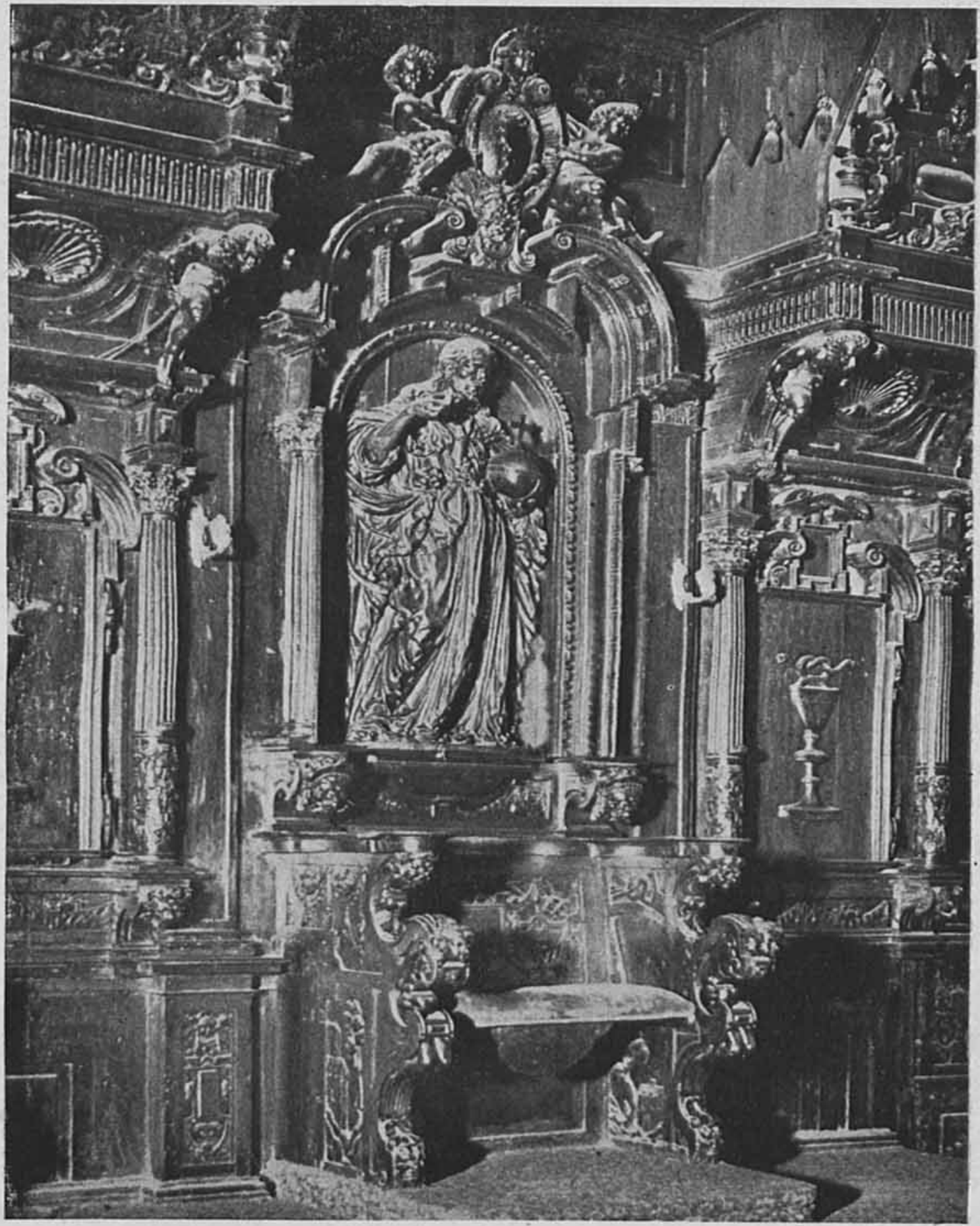

8. Respaldo de la silla arzobispal. 


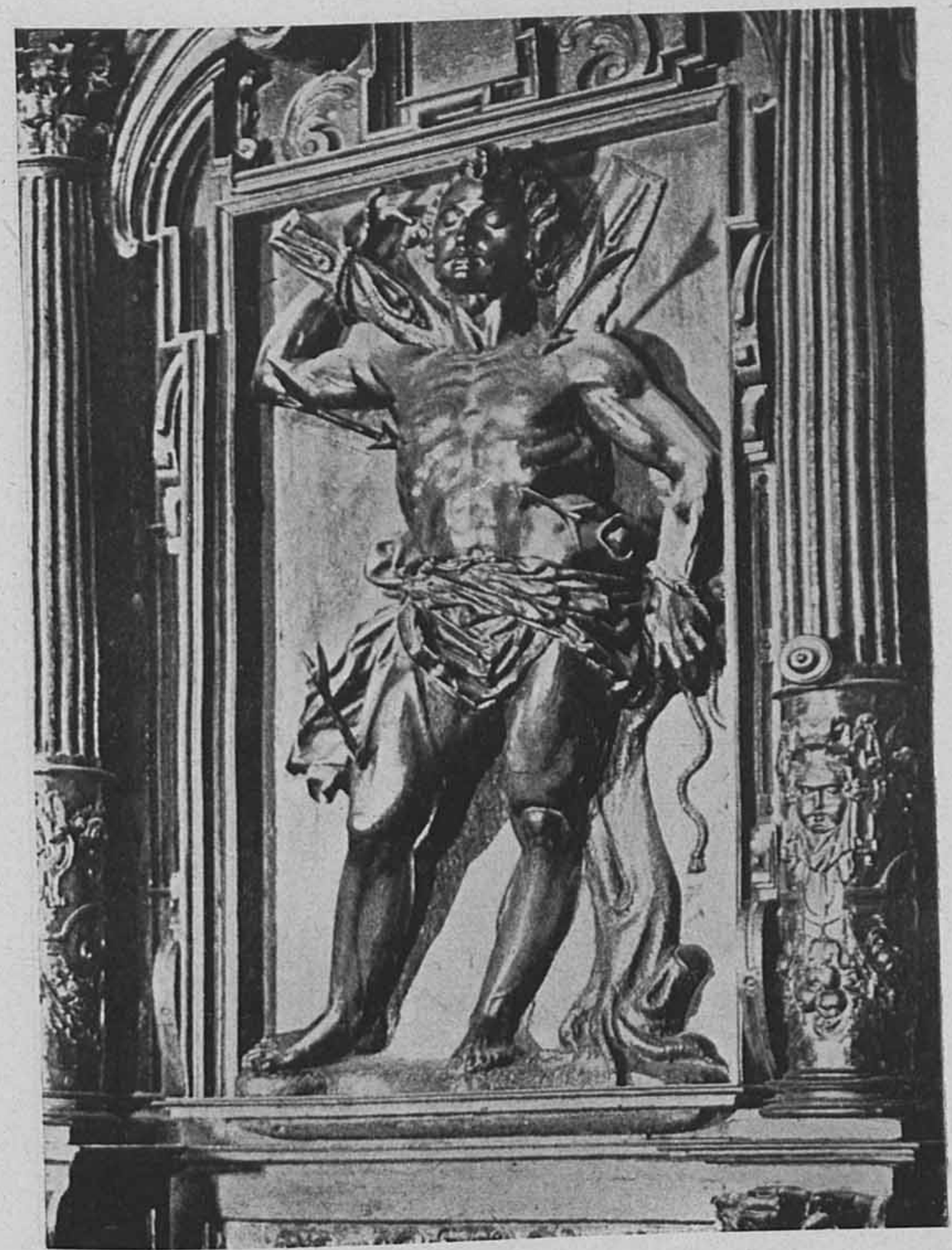

9. San Sebastián. Detalle. 


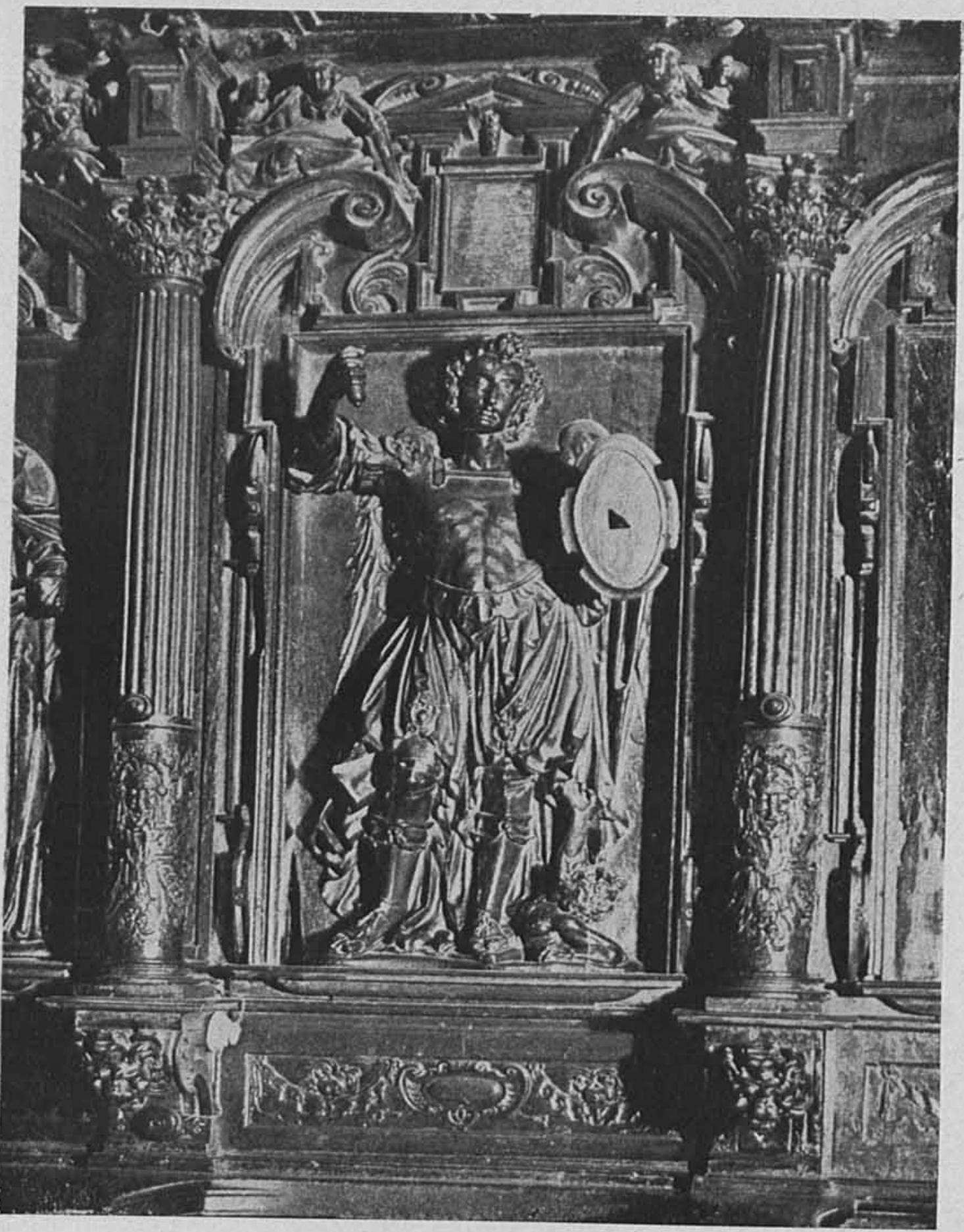

10. San Miguel. Detalle. 


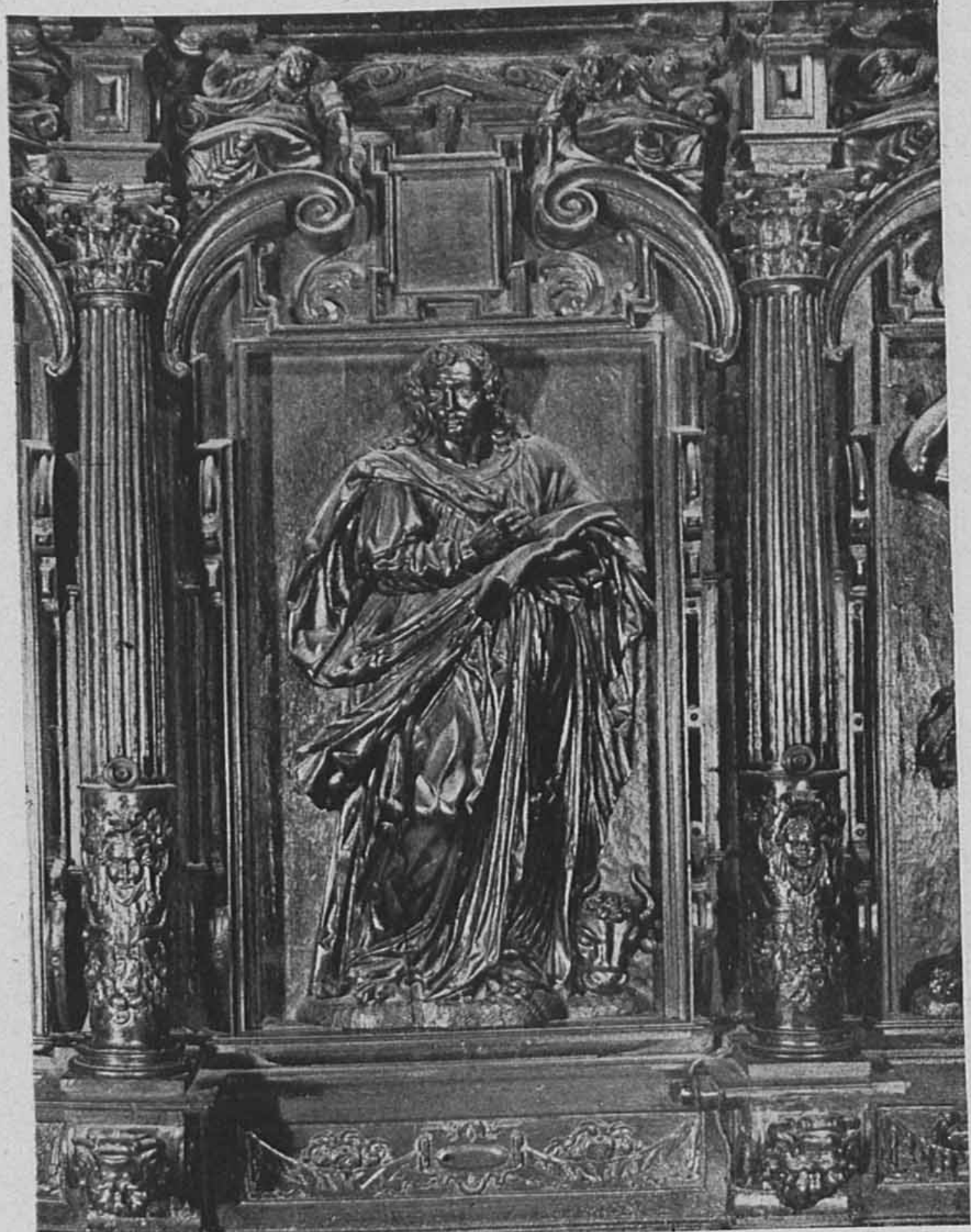

11. San Marcos. Detalle. 


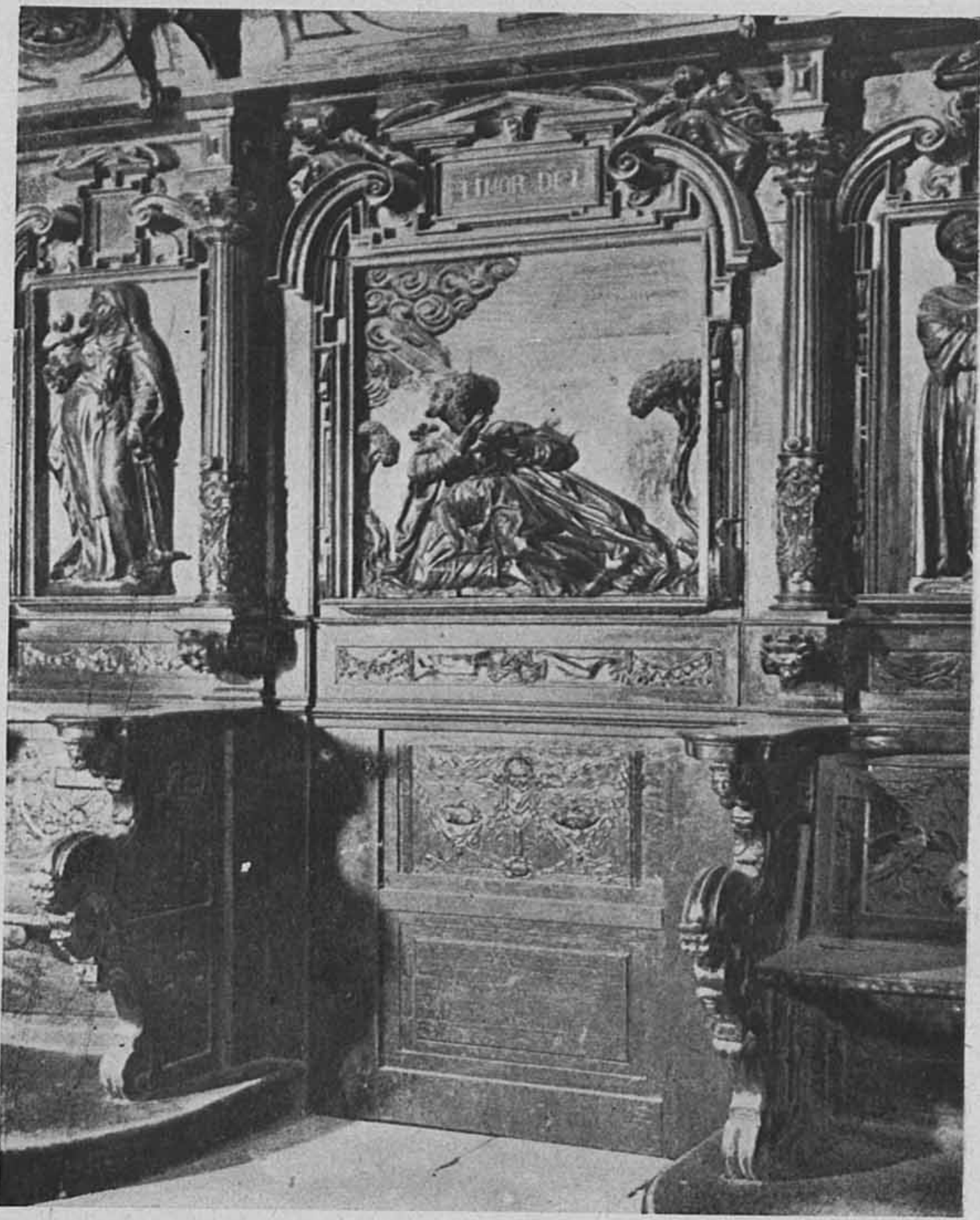

12. Puerta de comunicación a la Sillería. 
mible tampoco, aunque podría atrevidamente decirse que Noguera no llegaría a ejecutar tallado alguno y descargaría el peso en su socio y en sus ayudantes. Juicio o aseveración fuera de sentido ya que Noguera era verdaderamente escultor y esta posible afirmación, a pesar de la pintura que hemos hecho de su carácter oportunista, debe descartarse. Pedro de Noguera desde 1619 trabajó en escultura y retablos en Lima. Es larga la lista conocida de sus obras - y bien se sabe que las investigaciones de archivo sobre estos asuntos aun están en sus principios. $Y$ así como es presumible falleció hacia 1659 o 1660 a la ya avanzada edad de setenta años y hasta último momento estuvo ejerciendo su artesanía, dejando una de sus últimas obras en el bronce de la fuente de la Plaza de Armas de esta ciudad. 13

La existencia de esos dos ejemplares de arte virreinal en el mismo monumento: la Catedral de Lima, es un contraste de la mayor importancia. Nos descubre la transición en la escultura - y en parte, también en la arquitectura aunque sin tanta brusquedad- $y$ de las tendencias renacentistas primitivas y puras, a las acentuadas y movidas formas del barroco. Los dos maestros se enfrentaron en la misma obra: Martínez de Arrona, sencillo y humilde, ya de edad avanzada, último artesano del academismo; Pedro de Noguera, inquieto y ambicioso, paladín del movimiento exuberante del arte de la Contrarreforma. La arquitectura de Martínez de Arrona esta impresa del primer renacimiento y de las severas prescripciones herrerianas, en un conjunto que alegran los detalles de la arquitectura clásica romana del quinientos. Su escultura no podía escapar a estas orientaciones, que estaban grabadas en su espiritu. Martínez de Arrona, aunque escultor en sus primeros años en esta ciudad, era más arquitecto. Pedro de Noguera aunque se ensayó en este arte, sólo era escultor sobresaliente. La arquitectura era para él sólo el marco de sus esculturas y tallados: asi podemos juzgarlo en la exuberante y magnifica sillería del Coro de nuestra Catedral, mientras que para Martinez de Arrona, aunque se tildara de "escultor" (como eran muchos artistas del renacimiento, pintores y arquitectos) esto no era sino la alegría y el adorno de su arquitectura. Comparamos ambos conjuntos: la Sillería y la Cajonería. Destácase en la tíltima la composición orgánica de una fachada. Ia linea arquitectural predomina. En la primera, resaita el volumen de la escultura - aparte de ser ésta ya, el asomo del barroquismo. No es arquitectura lo que se entrevé de primera intención: uno busca algo más preciso y la

13 Antonio de Ribas fué el fundidor de elta pieza y el aguz corrió por ella en 1615. Su dibujo fué hecho por Pedro de Noguera. 
mirada tiende entonces a los detalles escultóricos y se detiene en cada uno de los magníficos tallados de sus santos mártires. La cajonería de la Sacristía puede verse en conjunto. Para la sillería hay que ir por partes; detalle por detalle. En verdad que en cada uno encontraremos algo nuevo, inspirador, motivo de múltiples emociones y comentarios. No es que la cajonería no reclame mayor atención, pero la vista de su conjunto inspira la calma y la tranquilidad. Luego podremos analizar cada una de sus figuras y nos detendremos ante su Salvador en éxtasis. $Y$ estaremos nosotros también así ante ella. Mientras que frente a la sillería nuestro espíritu se sentirá sacudido por la inquietud, y de una figura iremos a otra sin saber ante cuál detenernos, sintiendo el contraste de una y otra.

La figura de ambos maestros no se ha destacado suficientemente aún en el arte virreinal. Este trabajo no pretende tampoco hacerlo. Tanto de Juan Martínez de Arrona como de Pedro de Noguera hay bastante material acumulado como para un largo estudio, pero su tendencia se aparta de la escultura y el tallado: se relaciona más con ese renovar de fuerzas artísticas que surge en Lima desde el primer cuarto de siglo del xvIr. Es esta fecha como el crepúsculo de un sentimiento y la aurora de otro; trance que se realiza sin oscuridad de noche. Los rayos dorados del magnífico renacimiento se funden en las turquesas $y$ albores del barroco. No hay banderas ni partidos, aunque entre los maestros existia, como existirá siempre rivalidades de técnicas, pasiones de conocimientos y supremacias de escuelas; pero compartian todos la magnífica labor del arte en las obras de nuestra ciudad, y con esfuerzo, sus afanes, sus desvelos y triunfos lograban ir acumulando los sillares de esa grande e interminable pirámide de lo Bello cuya cúspide anhelamos descubrir y que fuga y se esconde en el inaccesible cielo.

Pero nada más natural para precisar mejor las dos épocas que ponerles un personaje al frente que las encarne con movimiento y vida, hacer humano el arte. No de otra manera podremos precisar la inquietud y las tendencias de cada instante artístico del pasado, en donde no se habló jamás de estilos, sino de maestros experimentados y de discípulos estudiosos; su arte cumplía una función técnica, materiales y necesidades regían los impulsos de la emoción y en esas raíces nutrian su inspiración.

Juan Martinez de Arrona y Pedro de Noguera, volverán a nuestras crónicas nuevamente y ya tendremos oportunidad de descubrir mejor lo apuntado arriba. En lo que se refiere a la Silleria del Coro y a la Cajonería de la Sacristía, no creo haber dicho todo lo que habría que decir, pero hagamos para este artículo un colofón del viejo refrán español: "quien mucho abarca, poco aprieta" y pongámosle final. 